\title{
COMMENTS ON THE PROPOSED RESEARCH PROBLEMS FOR THE ASSOCIATION COMMITTEE ON FORESTRY OF THE NATIONAL RESEARCH COUNCIL
}

\author{
by C. D. Howe \\ Dean, Faculty of Forestry, University of Toronto
}

$\mathbb{F}$

ORESTRY may be defined as the developing of the productivity of forest soils to meet the economic and social needs of a country through a long period of time. Continuity of production and stability of employment for labor are its basic objects. These can be attained apparently only by conscious effort in making provision for future crops. Successive crops may be accomplished by planting and by natural regeneration resulting from the method of cutting. Since the northern European countries (with forests, climates, and soils similar to ours) most experienced in developing highly productive forests are gradually abandoning or have almost completely abandoned artificial regeneration (planting) in the woods and are more and more depending on natural regeneration because it is just as effective and cheaper in the long run, I would place investigation of natural regeneration in the forest at the head of the list of projects to be considered by the Committee.

1 The carrying on of investigations that will lead to the devising of methods to get an adequate regeneration of spruce and pine after loggingoperations.

The first logical step in this problem is to find out what has happened in terms of regeneration on areas under the present logging methods. This would involve "regeneration surveys" on selected representative areas fifteen or twenty years after logging. The surveys should be applied both to areas logged without subsequent burning and to areas logged with subsequent burning. Our future supplies of the most valuable wood must come from such areas if the forest ind ustries are to be maintained, since virgin supplies of economically exploitable timber are limited in Eastern Canada at least. The cut over and burned over areas have the advantage of being located for the most part relatively near the mills. Therefore the determination of what to expect from such areas in terms of cordage of wood and time of harvest is of prime importance both from the standpoint of logic of procedure and from business considerations. Iu fact work of this nature seems so important and logical to me that $I$ believe the Associate Committee on Forestry would fully justify its existence if its efforts led to the solution of this problem alone, that is, a reasonable estimate of the contribution of cut over and burned over lands to the future supply of pulpwood and saw logs. 
The solution of the first problem indicated above might result in making unnecessary the second step in keeping the timberlands continuously productive, that is, possibly the annual growth of pine and spruce on the cut over and burned over lands equals the annual cut of those species. However, it is my considered opinion that such will not be found to be the case and the second step will be necessary, or in other words, the establishment of experimental cutting areas with the object of developing cutting practices that would lead to adequate natural regeneration of the most valuable species. Since the establishment of such areas would result in increased logging costs, a cost the operators are unable to bear under present conditions, some equitable adjustment of cost between the Crown and the operators would need to be made, and since it may be reasonably assumed that the owners of the land would profit most by the successful result of such cutting experiments, the simplest method would be the reimbursement of any additional cost of logging through a proportionate reduction of Crown dues.

\section{Increasing the yield per acre.}

The keeping of the forest soils continuously covered with a growing forest of the best commercial species is only the first and fundamental step in forestry. The second is to increase the yield in terms of cordage of wood. There is no reason to doubt that we could in time by proper treatment raise the yield per acre of spruce and pine to approximate that in the Scandinavian countries which is four or five times as much as nature undirected gives in our uncared for forests. The only way we can compete in foreign markets is to produce wood and its manufactured products cheaper than the other fellow and one of the best ways to do that is eventually to increase the yield per acre on the most economically exploited areas; concentrate on them and let the high cost areas take care of themselves. On authority of Professor J. H. White, Faculty of Forestry, University of Toronto, an area equivalent to one hundred townships of balsam and spruce if managed with the same care as certain European forests, would furnish enough wood to keep the pulp and paper industry of Ontario running indefinitely. An area equivalent to over 1400 townships is now under license for pulpwood cutting in the province. The concentration of logging operations upon high yield easily available areas would place the industries of eastern Canada on the most secure and enduring basis possible to compete in the world markets. Efforts toward the achievement of such a goal should be the principal object of a national forest policy. Of course it will take a long time to bring this about but this fact should not detract from its importance as an ultimate necessity.

One of the first steps toward methods of increasing the yield per acre is a study of forest soils in relation to their wood producing. capacity and the devising of methods by which soil quality. may be readily ascertained so that the work 
in the improvement of stands can be confined to sites that are naturally the most productive. Therefore I would recommend greater financial support for the work of this kind already begun by the Dominion Forest Service.

\section{Fire Privention.}

Excluding consideration of the possible fact that a well organized suppression service is in itself a preventive agency, one may say that much more public money has been spent on forest fire suppression than on prevention. This is illogical and wasteful. The old adage "an ounce of prevention is worth a pound of cure" never fitted a situation more completely than that of forest fires. Therefore I am in favor of the initiation of studies of projects that will lead to the greater effectiveness of prevention measures. These should include greater financial support for the investigation of forest fire hazards now being carried on by the Duminion Forest Service and a study of methods of making public education in regard to forest fires more effective than at present. The latter is fundamental because the people own most of the forests and they are responsible for most of the burning.

\section{Public education in the aims and objectives of forestry.}

One of the most impressive things observed on my Scandinavian trip last summer was the fact that while forestry was accepted by the public as a necessary practice-in one country for the past one hundred years-yet it is necessary to keep up a constant public agitation along educational lines. Eternal vigilance seems to be the price of forestry as well as of other worth while things. In these countries of course they have the advantage of being able to show the people what can be done through successful demonstrations. There are several organizations in each country whose business it is to see that the people visit forestry operations-school children, boy scouts, farmers' sons, young men taking their militia training, woodlot owners, and business men. In fact provision is made so that all these groups may take part in some phase of forestry work from a days time up to several weeks each year. And in addition to all this there is constant pressure on the public by really popular forestry magazines of wide distribution. I mean real forestry magazines, often with articles by farmers telling what they have accomplished with their woodlots, and by high school students describing their experiences in planting. If all this is necessary in countries of generally accepted and widely applied forestry practice how much more is it essential in a country like Canada.

We need elementary treatises on forestry for wide public distribution. These should include a simple A.B.C. pamphlet for workers in the lumbering and pulp and paper industries and another of a more detailed nature on farm woodlots to help the owners to manage them profitably. The Ontario Forestry Branch published a bulletin on farm woodlots nearly thirty years ago and it 
has since run through three editions. The Dominion Forest Service published another over twenty years ago. These bulletins have undoubtedly stimulated the interest of the farmers. Ontario for example has established over one inundred demonstration woodlots. However work in Ontario and in the Dominion at large has not been developed in a manner commensurate with its importance for after all the farmers of the country cut a larger volume of wood each year than the pulp and paper industry. In the older settled portions of the country the woodlot as an economic unit is gradually passing out of the picture and aggressive remedial measures should be taken at once. An attractive bulletin would aid in this direction but to be successful it must be supplemented by greater provision for coöperation between the government and the farmer in practical aid than exists at the present time. The objects could be accomplished for the Dominion as a whole by a revision and wide distribution of the Dominion Forest Service Bulletin 14, the reëstablishment on an active basis of the woodlot division within the Service and by the encouragement of greater activity by the various provincial organizations.

\section{Reduction in the cost of logging.}

I am in favor of the Committee initiating any studies that would reduce the cost of logging and increase the efficiency of labor but I am not competent to discuss them. It should be assured however, that the results of such studies would not lead to a still greater reduction of the forest capital at the expense of future needs.

In principle I am much interested in greater stability of woods labor and I think this can be attained best by the establishment of small farm holdings within the forest such as one sees so highly developed in the Scandinavian countries. The manager of a company with a half million acres of forest land told me that ninety per cent of his wood cutters did not need to go so far to work that they could not return home at night. Wood cutting is a trade handed down from father to son. Such forests are not purned and sustained yield is accepted as a necessary practice because the people realize that their livelihood depends upon the continuance of a productive forest.

6. Insect pests and forest pathology.

7. Forest prodiucts.

The govermmental organizations responsible for carrying on the work included in the above headings ( 6 and 7 ) have already demonstrated their usefulness and economic importance. Their need for greater financial assistance requires no argument.

I have outlined in the above paragraphs the projects I consider essential to a national forestry research program with a statement of nyy reasons in each case and have included only those things that would build a foundation for a comprehensive national forest policy. With the possible exception of fire pre- 
vention and reforestation by planting, which seem to be pretty well "sold" to the public, we need a great deal more factual data before we can formulate an intelligent forest policy. As I understand it, the function of the Committee is to initiate investigations that will furnish such data.

\section{Summary.}

In my opinion the most important fields of forestry research in Canada are:-

1. The determination of the growth and yield on cut over and burned over lands from the standpoint of their contribution to the future supply of commercial tinber.

2. The establishment of experimental cuttings on a commercial scale to determine what modifications of the present cutting methods may be necessary to secure adequate natural regeneration of the most valuable species.

( 1 and 2 of the summary are discussed under one heading in the text.)

3. Experiments in the treatment of the forest that will lead to greater production of wood per acre.

4. Studies in forest fire protection to make methods of prevention more effective.

5. Studies to make public education in forestry more effective.

6. Studies that would lead to a reduction in the cost of logging and increase the efficiency of labor.

7. Increased financial support for investigations of insect pests and forest pathology.

8. Increased financial support for forest products investigations.

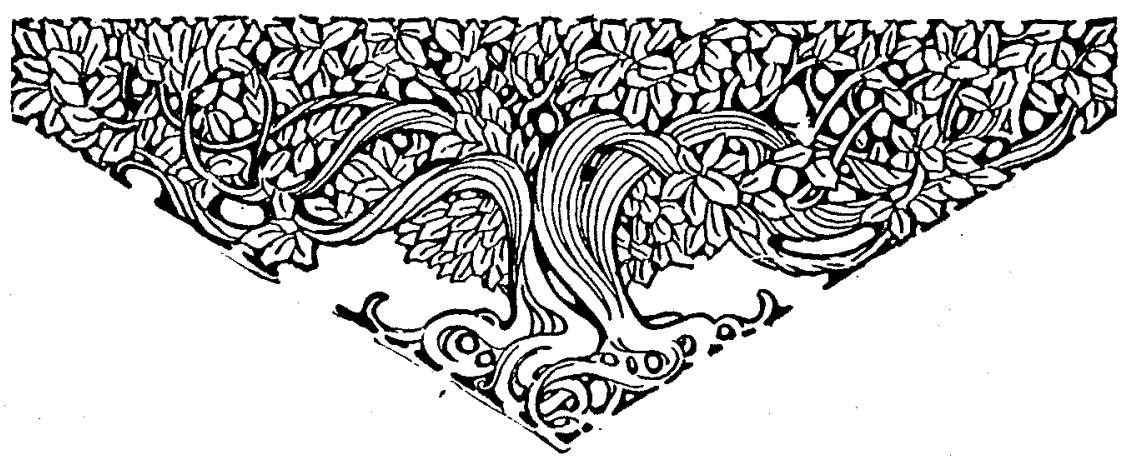

